\title{
COLONIAL EXHIBITION AND A LABORATORY OF MODERNITY: HYBRID ARCHITECTURE AT BATAVIA'S PASAR GAMBIR
}

\author{
Yulia Nurliani Lukito
}

During the 1920s and the 1930s, in the Dutch East Indies, there was a yearly fair held at the center of Batavia city. ${ }^{1}$ Pasar Gambir (Gambir Fair) was known as a modern exhibition and for its unique architecture that combined what might be described as "Indies vernacular" architecture with Western architecture. ${ }^{2}$ Every year, for about twelve days spanning August and September, the people of Batavia enjoyed the fair's exhibitions of modern and local products, technology, and arts and crafts, as well as entertainment, such as theater and cinema. Each year the architect of Pasar Gambir,

Yulia Nurliani Lukito wrote this article while a lecturer in the department of architecture, University of Indonesia, based on her years of research on architecture, fairs, and modernity while a doctoral candidate at RWTH Aachen University, Germany, mostly funded by German Academic Exchange Service or Deutscher Akademischer Austauschdienst (DAAD). The author thanks Lukito Priyambodo for his great support, and professors Axel Sowa and Henk Schulte Nordholt, as well as Indonesia's anonymous reviewers, for the helpful feedback.

1 The Dutch East Indies, or the Netherlands Indies, was the name for Indonesia during the Dutch occupation, until 1942. Between 1942 and 1945, the Japanese invaded and occupied Indonesia and, on August 17, 1945, Sukarno and Hatta proclaimed Indonesia's independence. Batavia was the center of Dutch administration and nowadays it bears the name Jakarta.

2 I choose the term "Indies architecture" to reflect what I understand now as "Indonesia vernacular" architecture, since, at the time, Indonesia was referred to as the Dutch East Indies. 
J. H. Antonisse, designed different pavilions using local architectural forms, and decorated the buildings with electric lights to emphasize modernity in the Indies. In addition to its Indies-Western hybrid architecture, modern exhibits, and consumerism, Pasar Gambir also offered a unique space of interaction between the colonizer and the colonized people.

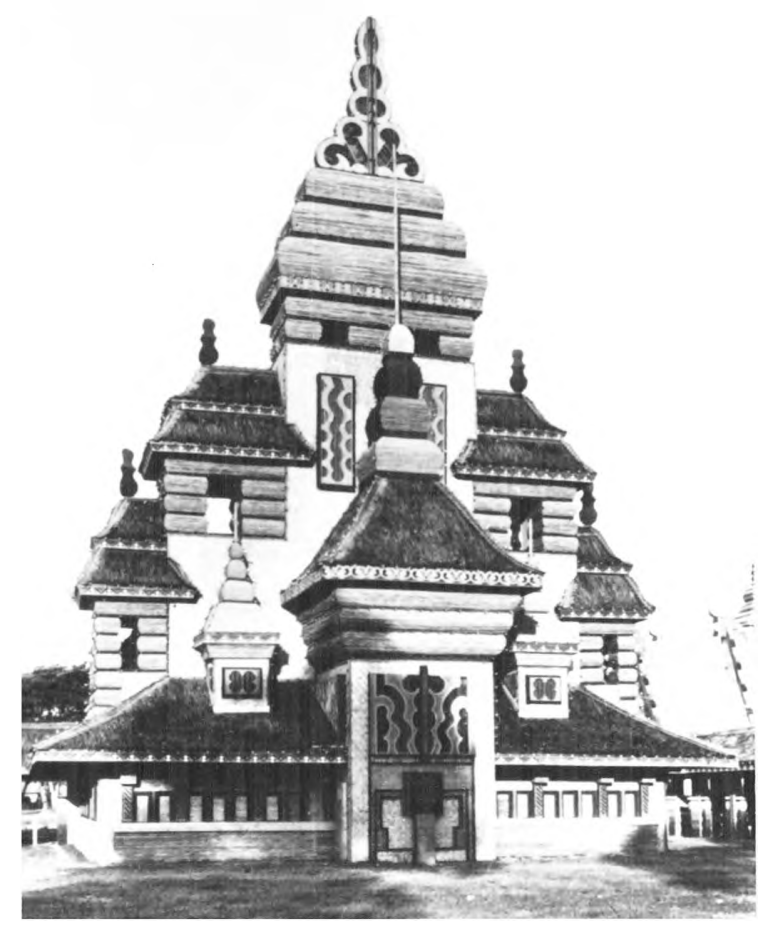

Figure 1: Batavia's 1933 Pasar Gambir Source: National Archive of the Republic of Indonesia

Some international exhibitions of the nineteenth and early twentieth centuries served as precedents for Pasar Gambir. In these exhibitions, national pavilions became points of attraction, and were where Western countries proudly used the architecture of their colonies to show off the glory of the nation. ${ }^{3}$ The Dutch, for example, used the vernacular architecture of the Dutch East Indies in every exhibition in which they took part. In 1889, the first international colonial exhibition was organized in Amsterdam, and Javanese kampong (villages) were built to represent the colony. The pavilions presented the glory of the Netherlands, including the progress of Dutch colonization. Besides promoting progress, these exhibitions were also a place where the unfamiliar, "exotic" cultures of the colonies were revealed to international audiences.

\footnotetext{
${ }^{3}$ For more discussion on international exhibitions of the nineteenth and the twentieth centuries, please see Paul Greenlagh, Ephemeral Vistas: The Expositions Universelles, Great Exhibitions, and World's Fairs, 1851-1939 (Manchester: Manchester University Press, 1988). See also Burton Benedict, The Anthropology of World's Fairs: San Francisco's Panama Pacific International Exposition of 1915 (London and Berkeley: Scolar Press, 1983).
} 
In the early twentieth century, enthusiasm for exhibitions reached the colonies themselves, and exhibitions were held in locations such as Jaarbeurs, in Bandung, West Java; the 1914 International Colonial Exhibition, in Semarang, Central Java; Jahrmark, in Surabaya, East Java; and Pasar Gambir. Those colonial fairs had experimental and hybrid characteristics, in that they exhibited both Western and local goods, culture, and architecture, and made extensive use of electric lights and contemporary advertisements. Although there were some other colonial exhibitions held in the Dutch East Indies, Pasar Gambir was held in Batavia, the center of Dutch colonial administration, and attracted the attention of large audiences. ${ }^{4}$ By consistently using local architecture, Pasar Gambir also demonstrated that Indies vernacular architecture - although adapted to fit different contexts-played an important role in modernizing the Indies.

After some years of research on colonial architecture in Indonesia, I found that colonial fairs have received little attention from scholars, in contrast to the broad discussions about the international fairs of the time. I believe that the lack of attention in discussing local colonial fairs has left an empty space in the historiography of modern Indonesia and a missed opportunity to better understand colonial society. This article analyzes the use of Indies vernacular architecture at Pasar Gambir, both as the source of inspiration for the fair and within the context of Batavia's urban modernity. The architecture and appearance of the fair was crucial in creating a perception of modernity within the colonial society of the Dutch East Indies. With the help of Pasar Gambir's unique architecture, local visitors were not merely controlled by the idea of modernity imposed by the Dutch, but, rather, engaged in cultural citizenship - a social participation in the claiming and negotiating of cultural space in modernity. ${ }^{5}$ (While it is true that the use of modern technology, such as machines and mass media, characterized the development of modernity, ${ }^{6}$ the idea of cultural modernity asserts that people are cognitively equal despite their physical appearance or the kind of technology they use. ${ }^{7}$ The cultural patterns of modern people reflect learned behaviors and are related to a function of social and cultural reproduction and learning. In this sense, the idea of cultural modernity gives an interesting perspective of how colonial society deals with cultural diversity, as well as the ability of Indies people to model modernity from their Dutch counterparts.)

Moreover, hybrid architecture presented at Pasar Gambir became a kind of lingua franca that was meant to unite diverse constituents of society and to make new connections between the ruler and the ruled. In the process of spreading modernity and consuming it, local audiences created their own understanding of modernity away from the script written by the authorities. Pasar Gambir became a laboratory of

\footnotetext{
4 This statement is based on my research on Pasar Gambir between 2011-14 in some university libraries, museums, and government institutions, both in the Netherlands and Indonesia. I found out that Pasar Gambir, more than other colonial exhibitions in the Indies, was very often discussed in newspapers and magazines both using Dutch (for example, D'Orient) and local language (for example, Pandji Poestaka).

${ }^{5}$ Henk Schulte Nordholt, "Modernity and Cultural Citizenship in the Netherlands Indies: An Illustrated Hypothesis," Journal of Southeast Asian Studies 42, no. 3 (October 2011).

${ }^{6}$ Marshall Berman, All that Is Solid Melts into Air: The Experience of Modernity (New York: Verso, 1983), 1617.

${ }^{7}$ Franz Boas, Race, Language, and Culture (New York: Macmillan, 1940).
} 
modernity for the colony, and an important stage in modernizing and negotiating cultural and social conditions in the Indies.

This article addresses the following questions with regard to Pasar Gambir. What kind of cultural and social interactions occurred at Pasar Gambir, and what was their relation to the spread of modernity for both the Dutch and local visitors? Given the participatory nature of the exhibition, how did Pasar Gambir-especially through its hybrid architecture-help local visitors create their own idea of modernity? By anchoring my case study to the fair during the late colonial period, I intend to present a cross-cultural understanding of how the architecture of the local fair contributed to creating participatory spaces and spreading modernity in the colony.

In analyzing the relationship between modernity at the fair, visitors to the fair, and the social and cultural interactions that happened at the fair, I draw on scholarship that discusses modernity, colonial exhibitions and hybrid architecture. I found that the ideas hybridity in every day life, as discussed by Mitchell and AlSayyad, offered a compelling way to relate the fair with hybrid architecture and space. ${ }^{8}$ Dutch anthropologist Henk Schulte Nordholt's idea that participation of local people in modernity causes people to feel a "cultural citizenship" underlies my understanding of Pasar Gambir. ${ }^{9}$ In addition, a sociologist Tony Bennet's discussion of late nineteenthand early twentieth- century museums and exhibitions as performative and instructive resources is useful for discussing how native visitors react in the fair. This suggests that colonial exhibitions instructed native visitors to act in an "appropriate manner," or like their counterparts, the colonizers. Finally, in discussing colonial exhibitions, Hoffenberg argues that colonial exhibitions institutionalized significant differences between settler and subject colonies while presenting opportunities to organize and participate in these distinctions. ${ }^{10}$

Benedict Anderson's concept of the "imagined community" - that the relationships we have to other members of the nation are imaginary and constructed-is critical to understanding the built environment of Pasar Gambir. ${ }^{11}$ Arguably, the architecture of Pasar Gambir worked as a sort of soft power that facilitated modernity and helped local visitors to improve their situation and to imagine the future nation. Even though I am inspired by the idea of "imagined community," my point of departure for this study is not the identity of community members as part of the same nation. Instead,

\footnotetext{
8 See Katharyne Mitchell, "Different Diasporas and the Hype of Hybridity," Environment and Planning D: Society and Space 15 (1997), 533-53. See also Nezar AlSayyad, "Hybrid Culture/Hybrid Urbanism: Pandora's Box of the Third Place," in Hybrid Urbanism: On the Identity Discourse and the Built Environment, ed. Nezar AlSayyad (Westport: Praeger Publishers, 2001).

${ }^{9}$ I would like to thank Professor Schulte Nordholt for his encouragement to connect Pasar Gambir with modernity in the Indies and our valuable discussions on colonial exhibitions that took place at KITLV, Leiden, the Netherlands.

${ }^{10}$ Peter H Hoffenberg, An Empire on Display: English, Indian, and Australian Exhibitions from the Crystal Palace to the Great War (California: University of California Press, 2001).

${ }^{11}$ Benedict Anderson, Imagined Communities: Reflections on the Origin and Spread of Nationalism (London: Verso, 1983).
} 
the departure point is the idea of community members with similar interests joining a new culture. This is closely related to the idea of "cultural citizenship."12

There was no Westernizing behavioral revolution in Indonesia, but, as Schulte Nordholt argued, there was an appropriation of modern attributes. Cultural citizenship is a response to the multicultural context of contemporary societies, including a concern with equality and difference. For Schulte Nordholt, middle class Indonesians were introduced to new lifestyles and invited to become a new, influential cultural group by means of education and commercial advertisements. Here I extend the idea of this appropriation of education and commerce to colonial exhibitions that provided hybrid space for interaction.

In doing so, first, I will analyze the meanings of the fair as both everyday pasar (market) and extraordinary fair in the context of the colony's urban modernity. Then I will discuss the architecture of Pasar Gambir, its prominent site, and the idea of hybrid architecture and space dedicated for cultural and social interactions. The last discussion will be on Pasar Gambir as an alternative space that is located at the border of everyday activities and festivities, and at the border of the ruler and the ruled. Though the Dutch government never meant to make a uniform citizenry of the Dutch and native populations, Pasar Gambir became an arena where the Dutch started to recognize the ability of the locals to adapt to modernity, and the locals learned about modern lifestyles that were previously almost out of their reach. Pasar Gambir, with its hybrid architecture, became a laboratory of modernity for the colony and an important stage in negotiating cultural and social conditions in the Indies.

\section{The Dutch East Indies' Most Popular Colonial Exhibition}

Pasar Gambir was a colonial exhibition held annually from 1921 until 1939 in the Koningsplein (King's Park), Batavia. ${ }^{13}$ Pasar Gambir was initially associated with the birthday of the Dutch Queen Wilhelmina, on August 31, and her coronation, on September 6, 1898. In subsequent years, the government in Batavia held some night fairs to celebrate the queen's birthday. Pasar Gambir consisted of hundreds of stands selling food, arts and crafts, and modern equipment, and featured various attractions such as music, theater, dance, movies, and sporting events. The 1925 Pasar Gambir, for example, had more than 230 stands, while the 1932 Pasar Gambir had around 190

${ }^{12}$ Henk Schulte Nordholt used cultural citizenship to relate the rising middle class in the Dutch East Indies to modernity. See Schulte Nordholt, "Modernity and Cultural Citizenship in the Netherlands Indies," 43557. Cultural citizenship responds to the multicultural context of contemporary societies, including the concern with equality and difference. The term was first used by the anthropologist Renato Rosaldo, to make a case for the democratization of institutions of higher education. See Renato Rosaldo, "Cultural Citizenship, Inequality, and Multiculturalism," in Latino Cultural Citizenships, ed. William V. Flores and Rina Benmayor (Boston: Beacon Press, 1997).

13 The last Pasar Gambir was held on August 25--September 6, 1939, just a few years before the Dutch surrendered to the Japanese (1942). After Indonesia declared its independence, the Jakarta governor reinstated this fair as the Jakarta Fair-a commercial fair. The location of the new fair was moved to Kemayoran and recently moved back to Koningsplein or, nowadays, Lapangan Monas. 
stands. ${ }^{14}$ Although the Dutch queen never visited her tropical empire, people in the Indies celebrated her birthday every year with fairs and festivities.

The Batavia city council initially organized Pasar Gambir with a limited objective of small scale trading and celebration. In 1904, Dutch colonial bureaucrats adopted this small fair into a business fair to promote both Western and indigenous products. Between 1907 and 1921 there was no regular fair, possibly due to difficult economic conditions and World War I. After 1918, the Batavia government created a committee to expand the scale of Pasar Gambir. The committee decided to add performance and entertainment areas to the fair as a complement to the areas for selling products.

In 1921, the committee gave the fair its official name, Pasar Gambir. ${ }^{15}$ As the fair grew, it attracted a lot of visitors, and made a significant profit for the government. The 1921 Pasar Gambir, for example, attracted more than 75,000 visitors in one week. ${ }^{16}$ Following the success of 1921's Pasar Gambir, the governor general granted a decree to create the Pasar Gambir Committee and empowered it to guide important aspects related to the fair, such as the budget and the design. The Pasar Gambir Committee consisted of twelve members from the Batavia City Council (Batavia Gemeenteraad), twelve members from the Local Council (Gawestelijke Raad), and twelve members from well-known merchant houses. ${ }^{17}$ This composition demonstrated the diversity of social and economic conditions in Batavia that included European, native Indonesian, and local Chinese, or peranakan, ${ }^{18}$ and reflected Dutch class divisions: indigenous people, foreign Easterners (including Chinese and peranakan), and Europeans. In other words, the committee represented colonial society: the Dutch were rulers and provided sophisticated technology; native workers supplied raw materials and provided the biggest market of consumers; and peranakan were the go-betweens who connected the Dutch with the natives living in rural areas.

Some Dutch and local newspapers covered the fair, such as D'Orient in 1927. Meyroos, the chairman of the Pasar Gambir Committee, said:

The moment when the bright lights are on ... the carousel spins, the giant Ferris wheel revolves and brings people up swaying ... (is) the moment when thousands and thousands of people crowd at the entrance to Pasar Gambir to get inside the living fairytale city of lights and pleasure ... ${ }^{19}$

During the 1920s and the 1930s, the Dutch architectural magazine Bouwkundig Weekblad Architectura (Architecture Weekly) covered Pasar Gambir, including in its 1936 edition:

14 From the Program of the 1925 and the 1932 Pasar Gambir.

15 “De Pasar Gambir En Haar Financien," D'Orient 3 (September 1927): 9.

16 Visitors to Pasar Gambir varied from 15,000 to 35,000 on a daily basis. Peter Keppy, "Keroncong, Concours, and Crooners," in Linking Destinies: Trade, Town, and Kind in Asian History, ed. Peter Boomgaard, Dick Koolman, and Henk Schulte Nordholt (Leiden: KITLV Press, 2008), 141-58.

${ }^{17}$ My translation of the term "Voorwoord," from The Official Program of the 1922 Pasar Gambir (Batavia, August 1922).

18 "Peranakan" is a term used for Indonesian Chinese or descendants of Chinese immigrants to the Indonesian archipelago.

${ }^{19}$ Meyroos, "Voorwoord Bij Het Pasar Gambir-Nummer," D'Orient (1927): 3. 
Entering through the large gate creates the sense of a big carnival, the brightly dressed up women from many parts of our archipelago, Chinese, Japanese, all moving quietly through one another. The great spotlight of the entrance tower casts its glow over the field and when the glimmers reach on the beautiful fountain this is the peak of brilliance and gives sparkle. From a technical perspective, the lighting is a genuine piece of art. Nowhere else the lighting installations shine, flicker, and dazzle the eyes; this (moment) can only be created through technology carried out by professionals and associated with mastery. ${ }^{20}$

A leading newspaper based in Singapore, The Strait Times, also covered the fair every year, for example, for the closing of the 1929 Pasar Gambir:

Tonight the Pasar Gambir closes. For months past it has been talked of; for months work was in progress transforming one corner of the Koningsplein into a vast market of atap buildings. For twelve hectic days and nights the miniature Wembley has been open, and tomorrow the work of demolition will commence. [...] What do all the people do in the pasar? Most of them seem to come away empty-handed; at the stalls they may be noticed eyeing the exhibits with curiosity and passing on without making any purchase. From the pockets of natives most of the money is probably spent at the refreshment stalls and in the amusement park; beyond that they are content to enjoy what can be seen free and to listen to the native orchestra or the wireless program. It is a relief from the monotony of kampong life, so they come from every where that is reasonably accessible. ${ }^{21}$

All of the statements above illustrate the popularity, the festivity, and the modern image projected by Pasar Gambir from the moment one passed through the entrance. The fair was associated with electric lights and leisure, two signs of modernity in the Dutch colony. The image of dressed up women coming from all over the country, as well as from neighboring Asian countries, demonstrates that the exhibition was a formal space, and visitors felt the need to dress up to join the crowd. The combination of the entrance tower and the light's effect at Pasar Gambir are described as creating a pleasant ambience at the fair as well as demonstrating the advanced technology used in this colonial exhibition. The discussion of Pasar Gambir in the prestigious Dutch magazine Bouzkundig Weekblad Architectura may indicate the importance of Pasar Gambir for the Netherlands, and references to the fair are written in a selfcongratulatory spirit, praising the Dutch for spreading the use of technology and modernizing the colony. The discussion also implies the ability of the colony to demonstrate the same mastery of electrical lighting as could be found in the Netherlands and, in general, to showcase the technological progress of the colony. The Strait Times mentions the unique attap (roof) buildings of the fair and names Pasar Gambir as a miniature Wembley for its popularity and festivity, a description underscored by calling Pasar Gambir a respite from everyday kampong life.

${ }^{20}$ Bouwkundig Weekblad Architectura was first published in 1881 by the Society of the Promotion of Architecture. The text is my translation of "Over De Pasar Gambir Te Batavia," Bouwkundig Weekblad, No. 57 (1936).

21 "The Pasar Gambir Again," The Straits Times, September 14, 1929. 
Pasar Gambir was a mixture of a traditional market and a modern fair; it functioned as a place for trading and entertainment. The word pasar in Bahasa Indonesian means a place where people buy and sell things.2- Pasar were usually constructed as semi-permanent buildings, often made from bamboo, wood planks, and a thatch roof. During the colonial era in Batavia, pasar was associated with a traditional market and commonly named following the day it was opened, such as Pasar Senen (Monday Market), or the name of the area, such as Pasar Tanah Abang.

The word fair, which is derived from Latin forum, or a public square, was originally synonymous with market. A fair is usually organized at regular intervals in a fixed location as a place where goods and services may be exchanged between sellers and buyers. A fair can also be used for political purposes, for example, it is where authorities can show off power as well as the land's economic and technological achievements. Both fairs and markets function as public meeting places, but a fair is implied to be a special gathering enriched with amusements. Pasar malam is Bahasa Indonesian for "night fair," for this kind of pasar was normally held at night and promised entertainment.

Pasar Gambir's name highlights the hybrid nature of this event. "Pasar Gambir" is a combination of the common term pasar with an extraordinary place for entertainment. This juxtaposition of the term pasar with Gambir - a highly exclusive neighborhoodwas intended to provoke curiosity and excitement in local people to cause them to want to experience an extraordinary event. By borrowing a familiar word from the native vocabulary, organizers hoped to encourage locals to join a hybridized event. The organizers intended to attract a great number of indigenous people, because they had the largest population and were thus the biggest market in the Indies. The use of the area Gambir was also significant. Koningsplein was a prominent site surrounded by government offices and important public buildings. The organizers made an effort to attract both Dutch and natives to this extraordinary event that presented hybridized experiences and modernity, as well as cultural and social variances in a central area.

Important government buildings, such as the palace of the governor general, Immanuel Church, the Royal Shipping Company, and the Museum of Batavian Society, surrounded Koningsplein. Main traffic arteries, the Dutch elite settlement, and public facilities-such as Gambir Station-were also located nearby, and Gambir trees (Uncaria gambir in Latin) grew around the square. The King's Park itself was well known for its big open space, with an area of 90 hectares (about 222 acres). Instead of calling the fair "Koningsplein's night fair," which was an ordinary name, the organizers chose to use "Pasar Gambir" in hopes of attracting many local visitors. For indigenous locals, going to a pasar in Gambir was an unusual activity, because the Gambir area was so closely associated with the authority of the Dutch colonial administration. For the Dutch, going to a pasar in Gambir was an exciting experience, since now there were a lot of natives coming to their main gathering place. It was the spectacle that attracted the Dutch and the natives, as well as the opportunity to experience cultural and social diversity. Thus, Pasar Gambir brought together people with disparate economic, social, cultural, and political perspectives.

${ }^{22}$ Kamus Besar Bahasa Indonesia (KBBI) online, "pasar," http://kbbi.web.id/pasar, accessed December 9 , 2014. 


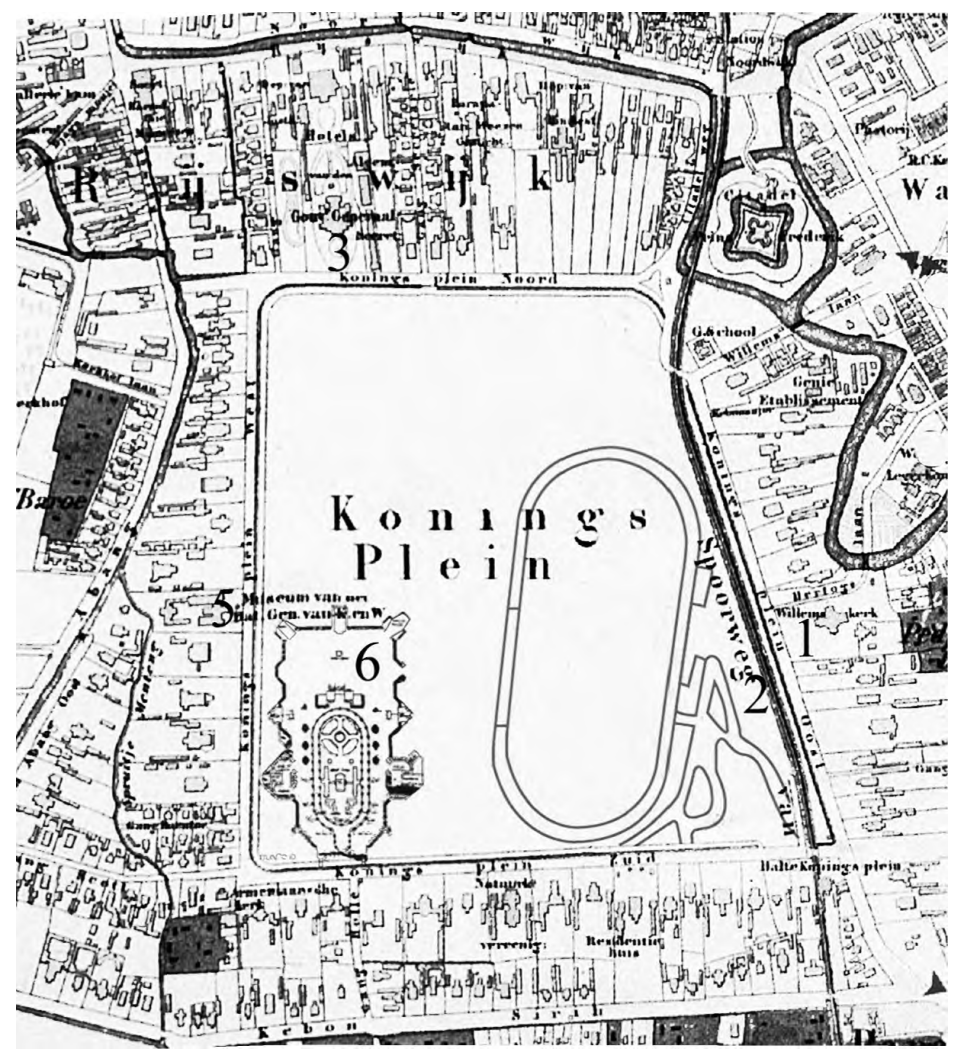

Figure 2: Pasar Gambir is the area marked "6" inside "Konings Plein"

Source: Compiled by author; National Archive of Indonesia and Allgemeen Rijksarchif

The English photographer Walter Woodbury, who resided in Batavia in 1857 for six months, took a lot of pictures of the city and wrote:

Koningsplein as it is called is the Hyde Park of Batavia and the residence of all the fashionables, amongst them myself. This part of the town is a perfect paradise with banyan and coconut trees and other beautiful trees (planted some forty years ago)..$^{23}$

In 1858, a visitor to Batavia, Weitzel, commented on Koningsplein:24

The Koningsplein, that is to say the roads bordering it, is the beloved walking place of that part of the Batavia population living in its vicinity. On each beautiful afternoon, between half past five and half past six, here one meets many carriages, pedestrians, and horse riders. With pleasure one moves in the middle of all that stir. The heat of the day has gone, the air has noticeably cooled off, and on the western horizon there is the beautiful glow of the already setting sun. New

${ }^{23}$ Woodbury, a founder of Woodbury \& Page photography, wrote to his mother about Koningsplein on May 26, 1857, as noted by Scott Merrillees, Batavia in Nineteenth Century Photographs (Surrey: Curzon Press, 2000), 161.

24 Ibid. 
zest for living flows through you and you regret that the sudden invading darkness makes so soon an end to your joy.

Woodbury compared Koningsplein to London's Hyde Park due to its central location and function as a public space. He even mentioned Koningsplein as a paradise, mostly because of its greenery. Weitzel illustrated the park as a beloved gathering place for Batavians, especially in the late afternoon when the air was cool. The mention of carriages and horse riders implied that some of the people who came to the park were wealthy. These two descriptions show that Koningsplein was a popular place for wealthy and fashionable people to gather.

The centrality of the King's Park was a physical reminder of the authority of the Netherlands over the region. Sastradarma, a Javanese aristocrat most likely from Surakarta, visited Batavia in the second half of the nineteenth century and was impressed by the association of the square with power. ${ }^{25} \mathrm{He}$ observed Batavia and the Koningsplein from a traditional Javanese perspective, that is, as a familiar center of a powerful kingdom. For Sastradarma, the power association in Koningsplein reminded him of alun-alun, or a big, open square located in front of a Javanese kraton (palace), possibly as having the same strong power representation. Alun-alun functioned as a center for public spectacles and court celebrations, and a place where ordinary people sought an audience with the regent.

In relation to town planning in the Indies, a Dutch architecture historian, Pauline van Roosmalen, argues that, in the Dutch East Indies, socioeconomic changes and demands for better infrastructure created a dynamic setting for the making of modern town planning in the first half of the twentieth century. ${ }^{26}$ Around the 1920s, some architects considered social and cultural requirements in their designs, such as zoning systems and spatial and hierarchical layouts. However, it was typical of architecture and urban design of the Dutch late-colonial period to use visibility and order as a representation of authority. One example can be found in the designs of the Dutch architect and urban designer Thomas Karsten. ${ }^{27}$

In 1923, Karsten was in charge of redesigning Koningsplein, although implementing his plans was suspended until 1937 due to unstable economic and political situations. He asserted the need to apply zoning to preserve both internal order and harmony between buildings and neighborhoods, and emphasized visibility among the centers, important buildings, and traffic to create a sense of order for the grounds. ${ }^{28} \mathrm{He}$ wanted to apply a kind of colonial reform that allowed him to engage both with the colonial hierarchy and cultural and social environment in a progressive

\footnotetext{
${ }^{25}$ Willem van der Molen, "Glory of Batavia: The Image of a Colonial City through the Eyes of Nobleman," in Urban Symbolism, ed. Peter Nas (Leiden: Brill, 1993), 327.

26 See Pauline K. M. van Roosmalen, “Designing Colonial Cities: The Making of Modern Town Planning in the Dutch East Indies and Indonesia, 1905-1950," International Institute for Asian Studies Newsletter, 2011.

${ }^{27}$ For a discussion of Thomas Karsten, see Joost Coté, "Thomas Karsten's Indonesia," in Bijdragen tot de Taal-, Land-en volkenkunde 170 (2014). For discussion on urban planning in the Netherlands East Indies, see Roosmalen, "Designing Colonial Cities."

${ }^{28}$ Abidin Kusno, The Appearances of Memory: Mnemonic Practices of Architecture and Urban Form in Indonesia (Durham: Duke University Press Books, 2010).
} 
way..$^{29}$ Karsten also used the principle of authority in a project to build pasar in Semarang, Central Java. He placed pasar strategically at the center of the city, and spatially organized it according to the classification of goods. He declared that in the Indies, the city was the center of order, and that the market was an essential part in the ordering of economic life to transform the primitive agrarian mentality of the population to an urban-ordered mentality. ${ }^{30}$ Pasar Gambir in Koeningsplein became a successful example of Karsten's idea that the market was a necessary element to change the mentality of visitors: to be modern and at the same time to recognize the Dutch's control.

The idea of Pasar Gambir as a colonial exhibition, the unique composition of its oversight committee, the focus on local audiences, and the significant location of Pasar Gambir gave this colonial fair a special character different from other late-nineteenth and early twentieth century international exhibitions. Although power relations determined the geography of King's Park and its surrounding area, Pasar Gambirwith its experimental architecture and festival ambiance-brought a new energy to Koningsplein. The festivities of Pasar Gambir offered a place for visitors to transform their daily life into something extraordinary. In other words, Pasar Gambir offered ambiguities to its visitors, who might recognize and acknowledge Dutch control, but at the same time experienced a relaxed relationship between the ruler and the ruled. The following discussion analyzes the fair's architecture, the people's reactions to the fair, and the relationship of the fair to modernity in the Indies.

\section{The Architecture of Pasar Gambir: The Lingua Franca of Indies' Architecture}

On September 5, 1925, D'Orient, Batavia's Dutch newspaper, published a special edition covering Pasar Gambir. In one of the articles, a leading architect and head of Batavia's Art Society in the Indies, P. A. J. Moojen, wrote:

The buildings [of Pasar Gambir] themselves were designed with knowledge of native materials and their form derived from native structures and assembled into architecture of decorative effect. The fanciful, picturesque silhouettes of Minangkabau and Batak houses [architecture] are excellently suited for such a temporary exhibition. But, moreover, it indeed demonstrates the vitality and the opportunity for Indies architecture to develop. And it is not only for the purposes of exhibition. ${ }^{31}$

Moojen credited Pasar Gambir not simply for its unique architecture, but also for its use of local materials and structures. The architecture of Pasar Gambir was a result of collaborations among a contemporary Dutch architect, who utilized modern architectural principles in his design, and tukangs, or local builders, who possessed the skills to build traditional houses (but perhaps had no formal education). As a result,

\footnotetext{
${ }^{29}$ Joost Cote, "To See Is to Know": The Pedagogy of the Colonial Exhibition, Semarang, 1914," Paedagogica Historica: International Journal of the History of Education 36, no. 1 (2000): 340-66.

${ }^{30}$ Thomas Karsten, "Town Development in the Indies," in The Indonesian Town, ed. W. F. Wertheim. et al (Hague: W. van Hoeve Ltds., 1958).

31 This is my translation of Pieter Adriaan Jacobus Moojen, "De Architectuur Van Den Pasar ('ambir," D'Orient 36 (September 1925): 15.
} 
the architecture of Pasar Gambir became a representation of what was modern at that time and demonstrated a potential development of Indies vernacular architecture in a modern context. Moojen's assertion was important because he took Indies vernacular architecture out of its colonial isolation and acknowledged a new moment for architecture in the Indies that did not correspond anymore to the previous strictly Western style.

At that time in the Indies, the search for a suitable architecture in the colony had become an issue. ${ }^{32}$ Though most of the Dutch architects preferred Western architecture, some architects desired a new architectural expression suitable for the conditions in the Indies. ${ }^{33}$ Moojen himself was in the middle of this discussion. He promoted the idea of supporting local architecture, and in 1926 even wrote a book on Balinese art and architecture. The famous Dutch architect Berlage, who visited the Indies in 1923, complimented Moojen's design for Batavia's Art Society as the beginning of modern architecture in the Indies. ${ }^{34}$ Moojen was very aware of the importance of local architecture as a source for design. Arguably, the success of Pasar Gambir might have strengthened Moojen's decision to use Indies architecture in his design, and later on he brought his admiration for Indies vernacular architecture to concrete manifestation for international events. His designs for the Dutch pavilion at the 1931 International Colonial Exhibition in Paris and the 1933 World's Fair in Chicago were based on Indies vernacular architecture. ${ }^{35}$

Each year from 1923 until 1939, the Dutch architect J. H. Antonisse built completely new buildings for the pavilions of Pasar Gambir; his designs were considered a creative use of local architecture. The architecture of Pasar Gambir showed the divergent ambitions of the Dutch to market the products of industry, promote modernism, and make money. The design and build of Pasar Gambir was the responsibility of Batavia's department of public works. In 1920, Antonisse, a selftaught architect, became chief of the public works department's engineering division. Starting in 1923, he was in charge of designing Pasar Gambir, replacing a Dutch architect named Cramer who had designed the fair for two consecutive years, 1921-22, and whose competent designs mainly accommodated the exhibition of products. As depicted in Figure 3, Cramer's design for Pasar Gambir started to use local architectural forms for the main gate, but the rest of the pavilions were less developed. Antonisse used his interest in Indies architecture for his designs and is recognized to have developed his personal architectural imagination in Pasar Gambir. For example, Antonisse chose Minangkabau architecture as the theme for the 1923 Pasar Gambir, his first assignment. In his early design, it seems that Antonisse simply mimicked the

32 The Dutch late colonial period in Indonesia was the period between the early twentieth century and 1942, when the Japanese invaded Indonesia. In 1908, the Dutch implemented the Ethical Policy that aimed to improve infrastructure, health, and education in the Dutch East Indies. One of the results was the growth of a local middle class by providing access to a modern educational system to many people.

${ }^{33}$ Iwan Sudrajat, "Indonesian Architectural History" (PhD Dissertation, University of Sydney, 1991). Yulianto Sumalyo, Arsitektur Kolonial Belanda Di Indonesia (Yogyakarta: Gadjah Mada University Press, 1993).

${ }^{34}$ H. P. Berlage, Mijn Indische Reis: Gedachten over Cultuur En Kunst (Rotterdam: W. L. \& J. Brusse's, 1931).

35 See Frances Gouda, Dutch Culture Overseas: Colonial Practice in the Netherlands Indies, 1900-1942

(Amsterdam: Amsterdam University Press, 1995), 194-236. 
horn-roof-shape of Minangkabau architecture for the pavilions, without reference to other types of traditional roofs.

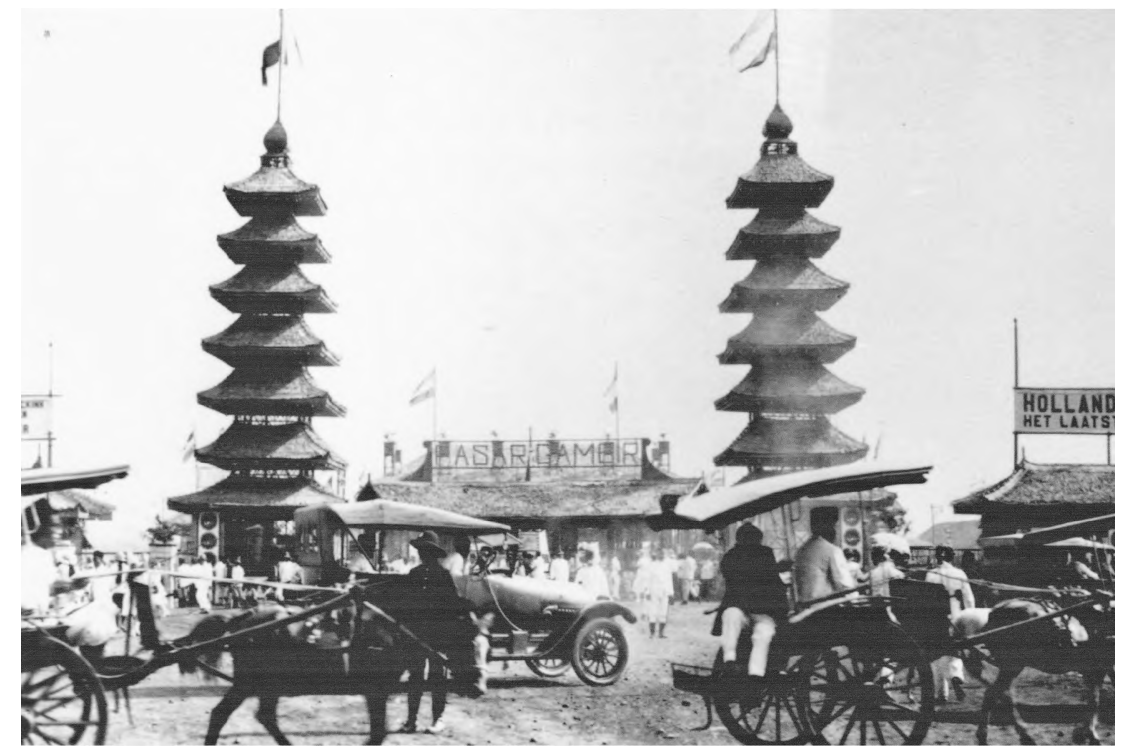

Figure 3: The 1922 Pasar Gambir

Source: National Archive of the Republic of Indonesia

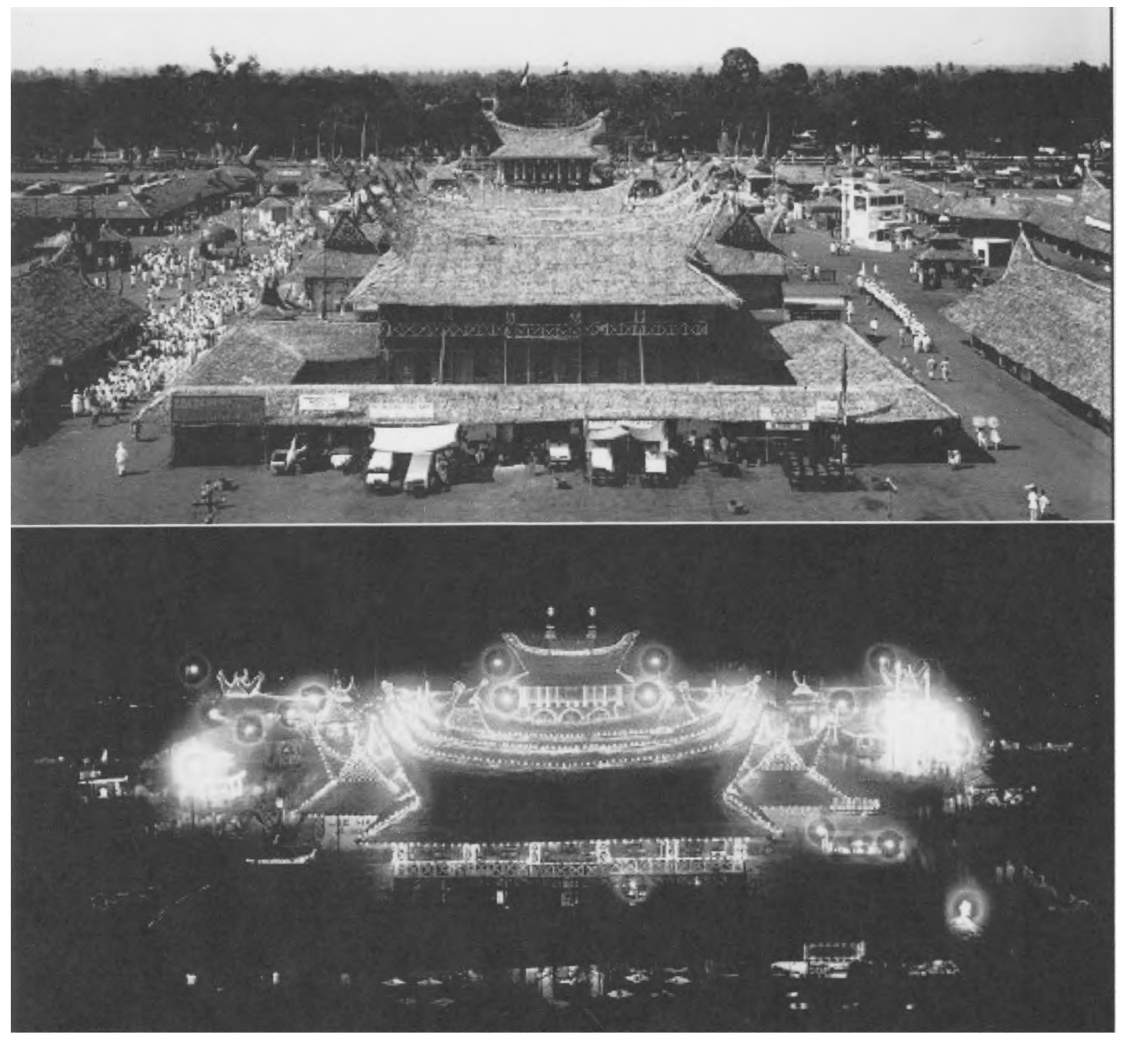

Figure 4: The 1923 Pasar Gambir during the day and night in a form of West Sumatra's horn-shaped Minangkabau architecture

Source: Nationaal Museum van Welerdculturen, Coll. Nr. 60029969 and 60029700 
The architect of the fair was praised for successfully creating an outstanding exhibition with an excellent architecture, as stated in the 1936 Bouwkundig Weekblad:

Since the department [of Public Works] has improved the overall design, the architecture of the fair is now upgraded; and it can be said that Pasar Gambir is as important to the Indies as, for example, the Foire de Lyon for the French. After using more Oriental styles at the beginning, [Antonisse] then gradually proceeds to design with more personal power and imagination without ever losing a connection with the surrounding Indies constructional forms. Similarly, he is not unfaithful to Indies construction materials, particularly native materials that can still be used by the poorest people in many parts of Java and Sumatra: bamboo and atap..$^{36}$

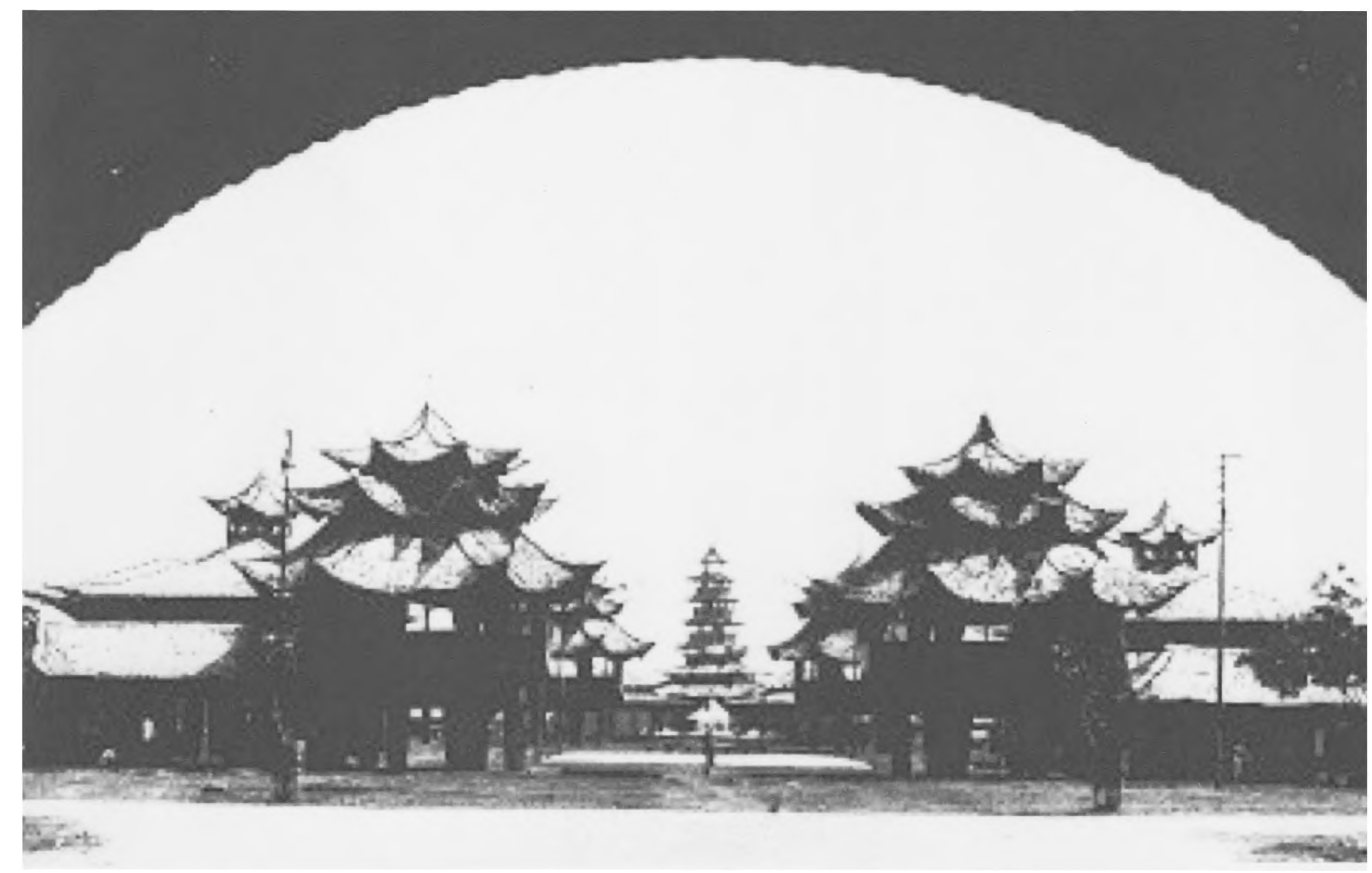

Figure 5: Entrance to the 1925 Pasar Gambir, with influences of Batak, Minangkabau, and Chinese architecture Source: Nationaal Museum van Welerdculturen Coll. Nr. 60019752

In the following years, Antonisse continued using local architecture as the basis for his designs and combined his themes with foreign architectural forms. As stated in the $D^{\prime}$ Orient that covered the 1925 Pasar Gambir, Antonisse used Indies architecture from Batak and Minangkabau, and combined them with Chinese architectural forms. ${ }^{37}$ As shown in Figure 5, he used a composition of several pavilions and entrances with three-tier roofs in a rather extreme curved-roof configuration, and placed them in several corners of the fair. The seven-tier roof of a Chinese pagoda, which was placed in the opposite direction of the main entrance, provided a climax to the architectural

${ }^{36}$ My translation of "Over De Pasar Gambir Te Batavia," 58.

${ }^{37}$ Moojen, "De Architectuur Van Den Pasar Gambir." 
compositions. There was not only a combination of Indies vernacular architectural forms, but also a combination of Eastern and Western architecture through the use of arches and the representation of a solid wall at the lower part of the pavilions. However, the Pasar Gambir pavilions lacked the details, proportions, functions, and contexts of the original architecture. This implies that the architect did not aim to copy exactly the local architecture, but rather used local architecture as a kind of catalog for his architectural experimentation. The colony was being inventoried and surveyed in Pasar Gambir.
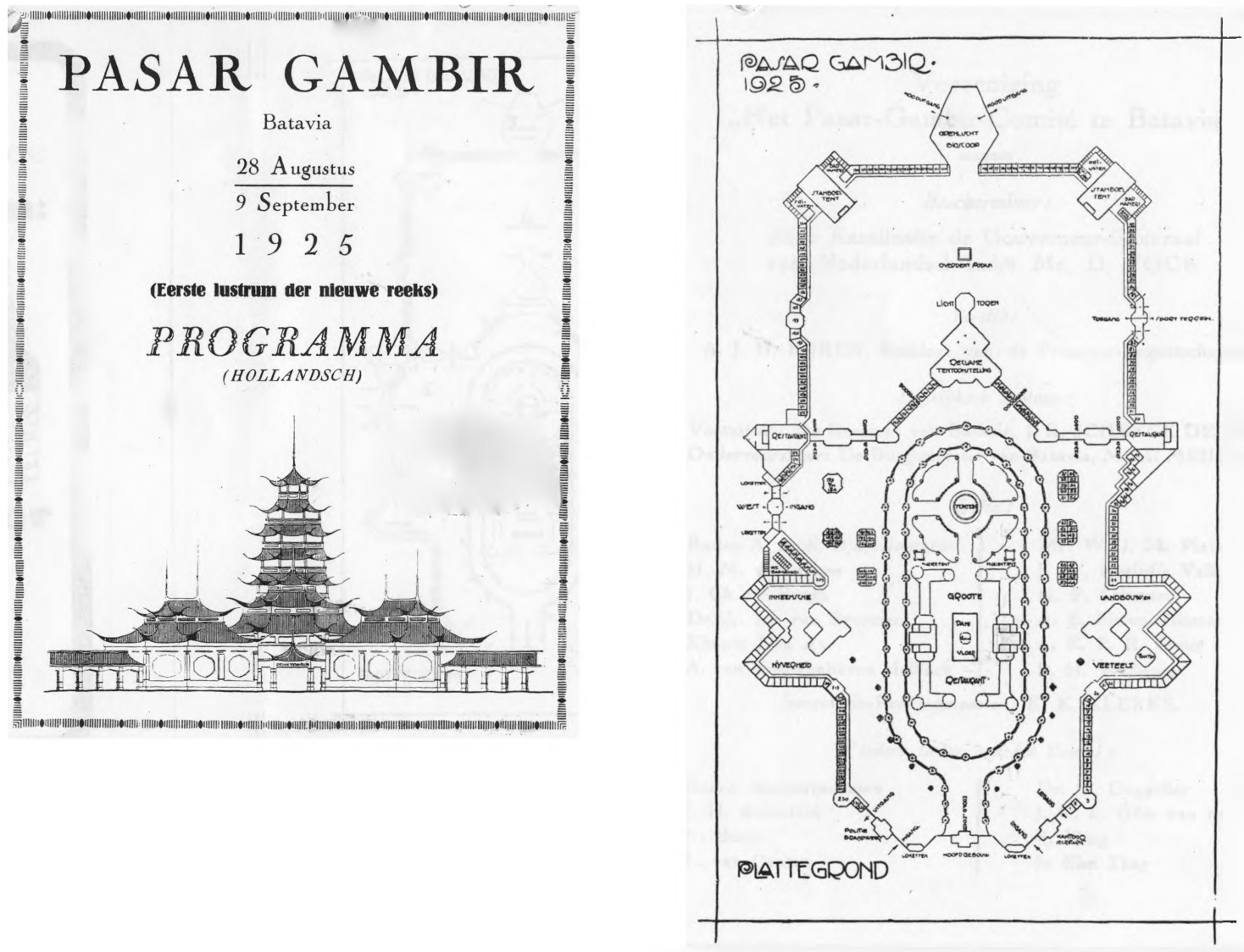

Figure 6: The visitors' program for the 1925 Pasar Gambir showed the fair's layout and elevation. Source: Programma Van Den Pasar Gambir

Antonisse also usually presented other common features of Indies vernacular architecture at Pasar Gambir, such as raised foundations and three divisions of a house or lower-middle-upper divisions. Since roofs were a dominant part of Indies vernacular architecture, Antonisse used local architectural forms generally and avoided copying a specific building. Therefore, visitors to Pasar Gambir could not actually see the association of the pavilions with Batak and Minangkabau architecture.

The arches at the 1925 Pasar Gambir became a frame that invited visitors to stop and understand the architectural composition before they walked inside the fair, as shown in Figure 5. By framing the fair at the entrance, the arches emphasized 
surprising experiences that visitors could expect. There was a composition of high and low as one came through the gate, and the culmination of that architectural composition was in the form of a pagoda placed above the horizon. Although only a small part of the fair, the gate framed the whole fair through a dynamic architectural composition of "up and down" and "the whole and its parts." It was the capacity of the gate to convey the fair's potential excitement to visitors and to facilitate visitors' initial investigation of the fair that foreshadowed Pasar Gambir's architectural power. Executed this way, it was obvious that the architecture, starting with the gate, was an irresistible invitation to visitors to enter a remarkable place. The open pavilions served as gates to entice visitors to enter the fair.

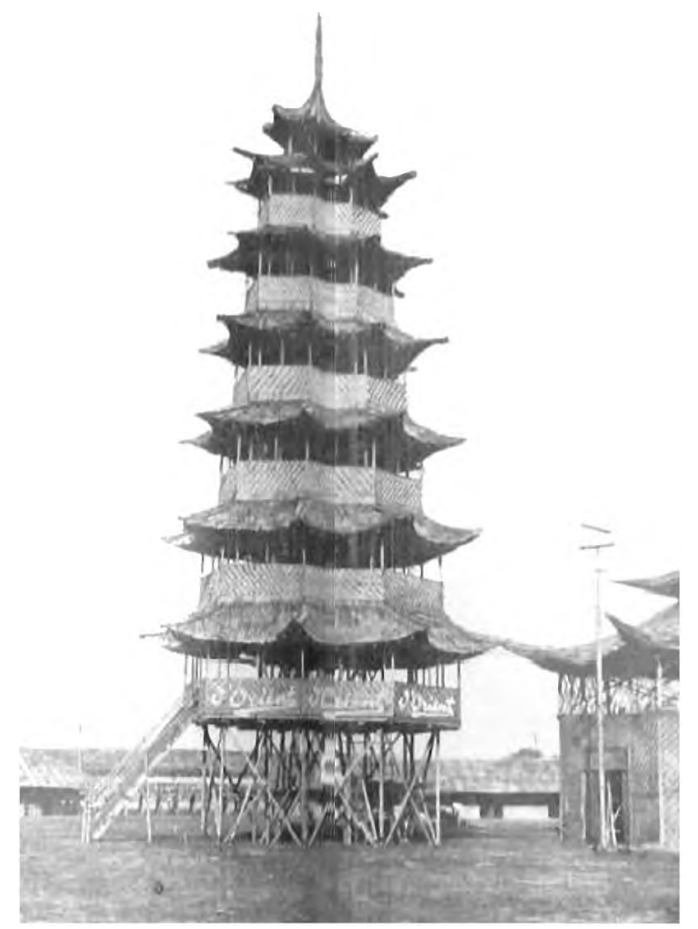

Figure 7: View of pagoda made of bamboos, wood, and palm leaves Source: D'Orient, September 1925

In the following discussion I situate Pasar Gambir in relation to hybrid representation of the colony in some colonial exhibitions. As noted earlier, the success of many international exhibitions during the late nineteenth and the early twentieth centuries influenced the Dutch to create Pasar Gambir. At these exhibitions, the national pavilions became a stage where countries could present their achievements, including those related to their colonies. ${ }^{38}$ In early exhibitions, the Netherlands pavilions were designed to show off the exotic culture of the Indies. Later on, the emphasis was on the progress of colonization, demonstrated by a hybrid design that

${ }^{38}$ For a further discussion on international exhibitions, please see Benedict, The Anthropology of World's Fairs and Greenlagh, Ephemeral Vistas. 
used modern architecture to represent the Dutch and vernacular architecture to represent the Indies. ${ }^{39}$ Those international exhibitions exemplified the importance of architecture as a medium to promote the identity that the Dutch wanted for themselves and their colony.

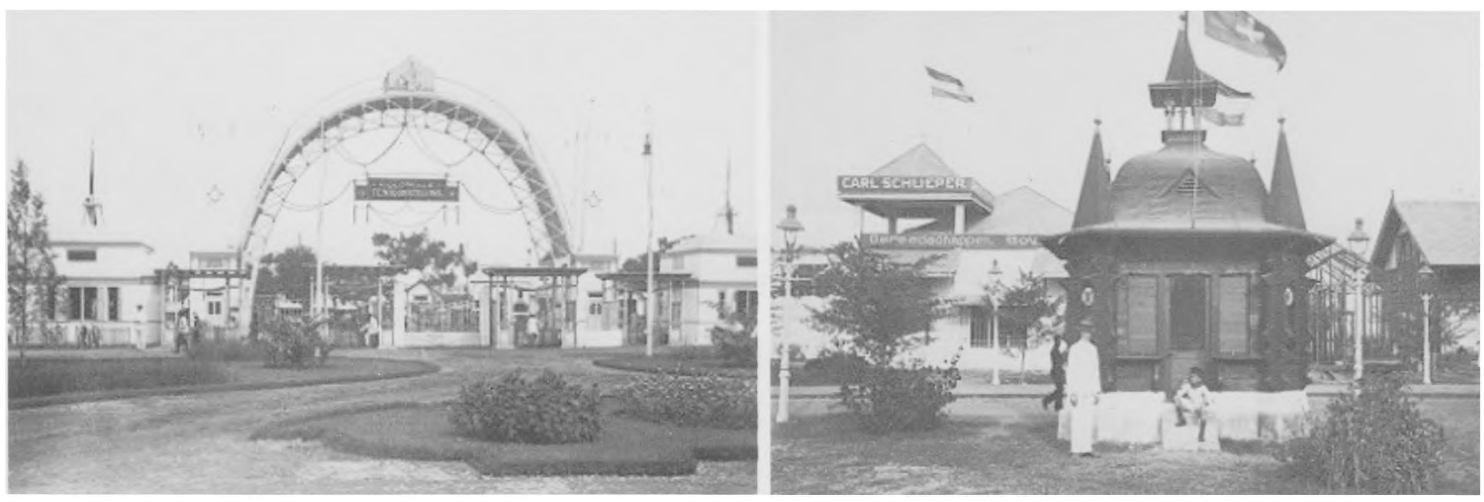

Figure 8: The entrance (left) and one of the pavilions of the 1914 Semarang Colonial Exhibition. Source: National Archive of the Republic of Indonesia and Nationaal Museum van Welerdculturen, Coll. Nr. 60039518

In 1914, there was also an International Colonial Exhibition in Semarang, Central Java; it was described as "the first large exhibition in the Indies." 40 This exhibition, opened on August 13, 1914, was intended to celebrate colonial progress in the Indies and served as a blueprint for a modernized Dutch colony.

One of the leading architects of that time, Henri Maclaine Pont, was assisted by Karsten in designing most of the pavilions for the Semarang Exhibition. ${ }^{41}$ The area for the exhibition was 26 hectares (64 acres), and included 600 meters of roadway, 1,067 meters of railway, and 105 new buildings. It was highlighted by electric and gas lighting, and Pont hired hundreds of native workers to construct it. Pont embedded modernity and progress in his design by using modern architectural forms, the latest techniques, and new materials to represent modern Dutch. Meanwhile, local architectural forms were located at the back of the site, "with buildings being discovered along a distinct yet rather mysterious pathway which would ensure that its heart would not be accessible to the public at large and thus be respected." 42 This colonial exhibition also included a Luna Park and incorporated the native as participant.

${ }^{39}$ Marieke Bloembergen, Colonial Spectacles: The Netherlands and the Dutch East Indies at the World Exhibitions, 1880-1931, trans. Beverly Jackson (Singapore: Singapore University Press, 2006).

${ }^{40}$ The first colonial exhibition in the Indies was a small exhibition held in Batavia in 1893. Another was held in Surabaya in 1911. Gedenkboek Van De Koloniale Tentoonstelling Semarang, 20 Augustus-22 November 1914, ed. M van Heel (Batavia: Mercurius, 1916), 1, 16, 110.

${ }^{41}$ Joost Coté, "Staging Modernity: The Semarang International Colonial Exhibition 1914," Indonesian and Malaysian affairs 40, no. 1 (2006): 1-44.

42 H. Maclaine Pont, “De Koloniale Tentoonstelling, Semarang 1914,” Nederlandsch-Indie Oud en Niew 191920 (1920): 47-64. 
The exhibition was organized under the supervision of the heads of the Colonial Administrative Divisions, aided by some representatives of the royal courts of Surakarta and Semarang's Chinese community. A wealthy Chinese family at that time, Oei Tiong Ham, provided the land and the money for the exhibition. The exhibition thus provided an opportunity for the Chinese to display their economic power and community position in a colonial setting. In brief, modernity and progress were embedded into the design and the operation of the Semarang Exhibition.

For Pont, the exhibition was also an expression of cultural differences. His statement that cultural difference should be presented through the separation of the modern and the traditional was very clear. This exhibition was not, however, successful, due to lack of support from the Netherlands and the onset of Europe's Great War (WWI) that same year. ${ }^{43}$ The site of the colonial exhibition was also far from Europe, and this decreased the likelihood of attracting European visitors. Unfortunately, there were only a small number of native visitors as well, probably because local visitors felt uncomfortable in these too-European surroundings.

There were varying ideas of hybridity in the Dutch pavilions created for international exhibitions held in Semarang and Europe. In colonial exhibitions held in Western cities, representations of the colony were generally read as the progress of Western civilization, and provided visitors with displays of the colonizer's power over its colonies. The pavilions in those exhibitions showed the importance of architecture to carry the message of constructed image that represented both the ruling and the dependent countries. The pavilions also represented a process of architectural experimentation, implemented in hybrid architecture, to find suitable architecture to fit a diverse audience. In Pasar Gambir, the architectural experiment was explicated publicly and the meaning of hybridity extended to the whole site as an alternative place-neither Western nor native-for both the Dutch and local visitors to interact. What happened in Pasar Gambir was an architectural experiment to facilitate the Netherlands' commercial agenda, an extraordinary space of interaction and an extension of modernity in the colony.

The success of Pasar Gambir made local architecture more popular than ever in the eyes of both the Dutch and middle-class locals. The use of hybrid architecture for colonial exhibition was also implemented for the Dutch pavilion for the 1931 international colonial exhibition in Paris, designed by two Dutch architects, Moojen and W. J. G. Zweedijk. Both architects presented the beauty of Balinese temples, combined with West Sumatra's buffalo roof, and a typical layered Javanese mosque that rose in tiers. ${ }^{44}$ The pavilion showed off a 110 -meter wide façade with two impressive Balinese pagodas. A wonderful Balinese kori agung (gateway) served as the main entrance, and a split gate, or candi bentar, as a second gate that led visitors to a courtyard. However, the interior of the Dutch Pavilion had modern influences, such as Art Deco. Hybrid architecture and the segregation between exterior and interior features of the pavilion describe perfectly the construction of identity between exotic

43 Coté, "Staging Modernity," 1-44.

44 The Dutch Pavilion covered more than three hectares (30,000 square meters), while the area for the main pavilion was 6,000 square meters. See the discussion on the Dutch Pavilion in Bloembergen, Colonial Spectacles, 269-302. 
colonies and their modern colonizer countries. ${ }^{45}$ Since visitors were mostly Europeans, this kind of hybridity helped the Westerners to nourish their fantasy for things exotic.

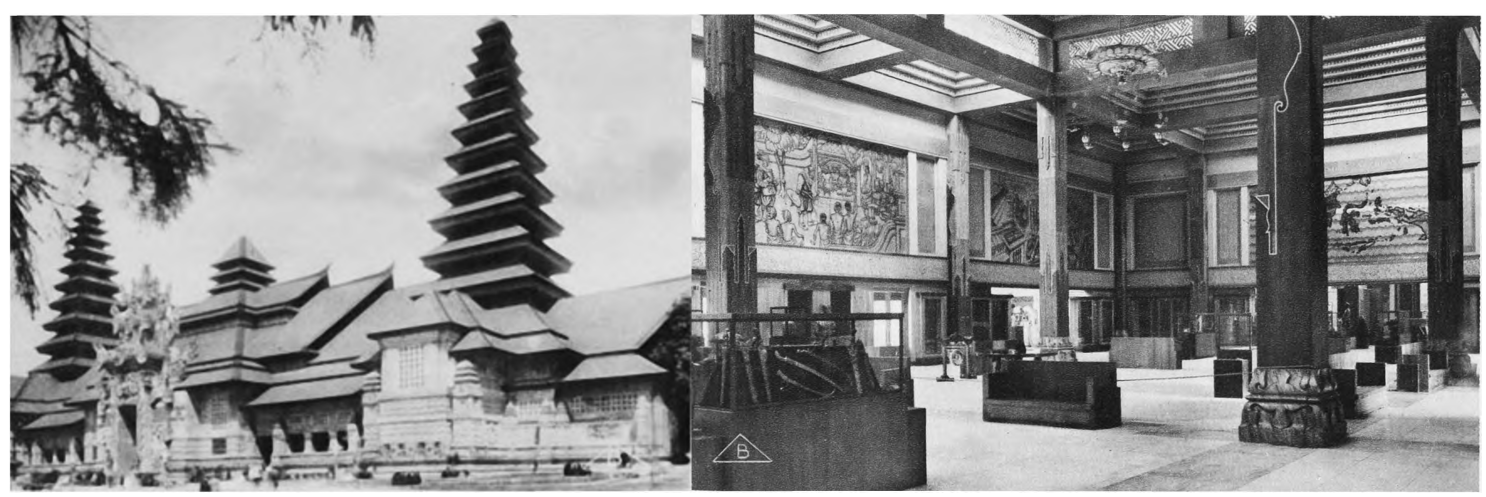

Figure 9: The exterior and the interior of the Dutch Pavilion at the 1931 Colonial Exhibition, in Paris. Source: University Library Leiden (KITLV)

Pasar Gambir's architecture was distinct from the permanent buildings being constructed during the 1920s and the 1930s in the Dutch East Indies. Before the nineteenth century, it was common for Dutch colonials to build houses that were copies of their counterparts in the Netherlands, in a neoclassic style. This kind of building, largely known as the Empire Style, featured Greco-Roman columns and used symmetrical principles. This style was a favorite among Dutch authorities and Indonesian ruling elites, and was considered a sign of authority and prosperity. The Javasche Bank, for example, in 1827 adopted this style as a part of its official trademark style (all bank branches had Greco-Roman columns) and some offices and houses built for bupati (the Dutch-appointed Indonesian regents in Java) also incorporated this style, which glorified the connection to the source of colonial power.

To deal with the tropical climate, builders and architects gradually learned from local designs and replaced unsuitable neo-classical architecture with local forms and materials. There were some architectural adaptations that appeared in the designs, such as a large opening for cross ventilation and an extended roof edge to divert direct sunlight and rainwater. Houses for the Dutch and local wealthy families now had a large veranda that derived from the traditional Javanese pendopo (a covered open space or pavilion). Traditionally, the pendopo was located between the house's public and private areas. In the Dutch hybrid buildings, it became an extended veranda that served as a multipurpose space for both family activities and entertaining guests. The Dutch now embraced not only local architecture, but also local social norms and lifestyles, and the Empire Style was deemed inappropriate to that time and place. This hybrid architecture of European and indigenous architecture was known as "IndoEuropean style." ${ }^{46}$

${ }^{45}$ Patricia A Morton, Hybrid Modernities: Architecture and Representation at the 1931 Colonial Exposition, Paris (Cambridge: MIT Press, 2000).

${ }^{46}$ Sudrajat, "Indonesian Architectural History." 
One of the first independent architects in the Netherlands East Indies to consider local conditions was Moojen, who worked in a contemporary architectural style. ${ }^{47}$ For example, in addition to classical elements, Moojen used a double façade on the ground level and a built-in gallery on the upper floor to address the issues of direct sunlight and rain. Moojen might have explored Indonesian vernacular architecture to a greater extent. He was interested in Indies architecture, and had emphasized the visual aspect of it in many of his designs, but he never took any of the local people's socio-symbolic values into consideration. For example, in creating the Dutch pavilion for the 1931 Paris Colonial Exhibition, Moojen modeled his design on a Balinese temple, but he changed the sacred-profane order of the space.

Alongside the development of the Indo-European style, there was also a growing idea of finding the "architecture of the age" in the Indies during the 1920s. ${ }^{48}$ Some architects employed experimental design projects, discussions, and lectures to express themselves and to respond to the idea of just such a new architecture. Karsten and Pont were two architects concerned about the dominance of European architectural expression and the gradual extinction of indigenous architectural traditions in the Indies. Both of them were seen as "hybrid architects" who used local architecture that would eventually reconcile indigenous architectural tradition with its European counterpart. Karsten exploited both Western and indigenous materials and constructions; for instance, by incorporating pendopo for the Mangkunegara palace, in Solo (1923), and for a Sobokarti theater (1930). His design for Pasar Johar (1933), in Semarang, reflected his consideration of local conditions. ${ }^{49}$ Pont was inspired by local materials, techniques, and stylistic elements-especially by making a modernized version of the pendopo-when he designed a Catholic church in Pohsarang (1936). Pont and Karsten quoted architectural elements from various places in their work, and their architecture transcended the cultural context to which the elements belonged.

Pasar Gambir was one example where architectural experiments were visible to the public. The fair's architect selected icons of traditional Indonesian architecture and used them as his vocabulary in his designs; he did not question culture, but repackaged it in order to give comfort to the audience.

Hybrid architectural form was created when Pasar Gambir's architect removed local architectural references from their traditional contexts and combined the local forms with modern architectural principals. The experimental architecture did not belong to any ethnic or social group, and was not intimidating to either the colonizers or the colonized people. As a result, Pasar Gambir's architecture was easy to consume and gratified communal experiences. This lingua franca of architecture, which represented commonality among Indies architecture, allowed natives to understand

${ }^{47}$ C. J. A. Gokkel, "Bouwkunst Te Batavia," Bouwkundig Weekblad 2 (1907): 18-20.

${ }^{48}$ For further discussion on architecture in the Indies during this era, I used mostly Hellen Ibbitson Jessup, "Dutch Architectural Visions of the Indonesian Tradition," Muqarnas 3 (1985); and Cor Passchier, "The Quest for the Ultimate Architecture Indonesia in the Late Colonial Period," http://www.pacnl.org/downloads/thequestfortheultimatearchitecturecp08kopie.pdf, accessed August 3, 2015.

${ }^{49}$ Karsten used modern ideas (e.g., a mushroom-like structure) to accommodate the need for open and high space, and designed the kiosk by considering the needs of local traders (e.g., those who used slings and carried their goods on their backs). 
that the Indies consisted of a multiplicity of ethnic groups and arguably provoked a sense of a shared identity. ${ }^{50}$

\section{Creating Localized Modernity and a Space of Encounter}

Pasar Gambir presented the idea that modernity could include everyone in the colony. The fair's hybrid architecture became a marketing device for its commercial, social, and cultural purposes. However, Pasar Gambir was basically a celebration of spectacle and modernity. For example, the main pavilions acted as entrances to the fair, through which visitors saw the crowds and the exhibits. The openness on the pavilions' lower levels directed the crowds, as well as acting like display windows to advertise the exhibits available inside. There was an illusion of social equality that disguised the commodified status of the exhibits displayed within. The gate played a crucial role in redefining the territories intended for the Dutch and natives. The gate to the fair became a boundary that encouraged people outside the fair to experience modernity and helped them to transform their daily lives into a hybrid experience. Once visitors entered the fair, the Dutch and the local people exchanged gazes and those gazes arguably were more powerful than the image of the Dutch authority in Koningsplein. In this sense, social contact became the most valuable product that Pasar Gambir promised and delivered.

The unique social contact between the Dutch and natives was important in Pasar Gambir, thus it was possible to connect the fair with Batavia's urban modernity to understand the social conditions during that time. Batavia was a center of Dutch colonial administration and functioned as the Netherlands' entry to Dutch East Indies' goods and markets. Batavia transformed colonial relations into experiential reality through its colonial architecture and urban planning. ${ }^{51}$ Pauline van Roosmalen stated that although there was a legal division of ethnic categories and separate areas for living quarters in Indies society, it was still possible for people from different social categories to live and interact in the same area. ${ }^{52}$ During the early twentieth century, some town planners and municipalities started to practice a socially conscious approach to municipal planning. Thus arose the idea that a city's modernization was not only functional, but also an aesthetic and sociological ideal, inasmuch as the built environment provided an opportunity for different groups to interact.

\footnotetext{
${ }^{50}$ In a linguistic context, lingua franca means a vehicular (common) language used in communication among members of societies whose own (native) languages are different. A vehicular language is used to allow people of diverse backgrounds to communicate orally, usually uing a basic form of speech and simplified grammar.

51 Zeynep Çelik discusses colonial architecture and urban planning relative to different colonized groups, and also argues that certain sociopolitical and cultural trends of both East and West were mirrored in the architecture of colonial exhibitions. See Zeynep Çelik, Displaying the Orient: Architecture of Islam at Nineteenth-Century World's Fairs (Berkeley: University of California Press, 1992).

${ }^{52}$ For example, well-to-do Chinese and indigenous people who were either high-ranking or in domestic service might live in the same area or in the immediate neighborhood. See Pauline K. M. van Roosmalen, "Netherlands Indies Town Planning: An Agent of Modernization (1905-1957)," in Cars, Conduits, and Kampongs: The Modernization of the Indonesian City, 1920-1960, ed. Freek Colombijn and Joost Cote (Leiden: Brill, 2015), 87-119. See also her "Designing Colonial Cities."
} 
The fact that Pasar Gambir was created in the early 1920s and became immediately popular was not coincidence. The final occupation of the Indies occurred in the 1920s. During this time, there was already a significant extension of modernity through advancing a modern school system, modern technology, and consumerism. All led to the emergence of a plural society that welcomed change and progress. Historian Takashi Shiraishi called this time zaman bergerak, or "an age in motion," for there were changes in many aspects of colonial life. ${ }^{53}$ In this era of progressively modern influence, it was local people who spread the idea of movement and change, and not merely the Dutch or nationalist representatives. The Dutch sociologist J. A. A. van Doorn stated that the Dutch late-colonial era had a role in developing the modern Indies because the Dutch started to appreciate the results of change and progress, as well as adjust their attitudes about class and cultural differences. ${ }^{54}$ In short, simultaneous with the era of colonial exhibitions, there was also the emergence of modernity, and a possibility of economic, cultural, and social negotiation between the colonizer and colonized people.

I believe that the idea of hybridity as a lived experience can explain the unique sense of identity shared in a context like Pasar Gambir. ${ }^{55}$ At first the idea of hybridity, which was raised in the eighteenth century, invoked biology to justify ideologies of White racial superiority. This physiological concept of hybridity progressed into a racial theory in the nineteenth century and expanded in the twentieth century to include cultures and languages that derived from heterogeneous sources. ${ }^{56}$ In a postcolonial study, Homi Bhabha explores hybridity as the resilience of the subaltern and as the contamination of imperial ideology, aesthetics, and identity by natives, who are striking back at imperial domination. ${ }^{57}$ In describing a cultural mixing generated by colonialism, Bhabha asserts that hybridity did not emerge from the synthesis of different entities, but, rather, from a space where elements encountered and transformed each other.

Though Bhabha's explanation is compelling, I prefer to relate hybridity to common practice rather than theory, in order to recognize the dynamic of social and cultural relations and to emphasize the agency of people. Some intellectuals, such as Katharyne Mitchell, do not believe that Bhabha's abstract can be applied far enough to consider cultural boundaries. For Mitchell, hybridity can simply be a personal identity. Meanwhile, AlSayyad states that hybridity must be considered in its tangible, daily expressions, rather than just in theory. ${ }^{58}$ Thus, hybridity can be understood as a lived

\footnotetext{
53 Takashi Shiraishi, An Age in Motion: Popular Radicalism in Java 1912-1926 (Ithaca: Cornell University Press, 1990).

${ }^{54}$ Jacobus Adrianus Antonius van Doorn, De Laatste Eeuw Van Indië. Ontwikkeling En Ondergang Van Een Koloniaal Project [The Last Century of the Indies] (Amsterdam: Bert Bakker, 1994).

${ }^{55}$ According to the Oxford English Dictionary, the word "hybrid" is originally derived from the Latin for offspring "of a tame sow and wild boar" or "human parents of different races."

56 See: Patrick Young, "From the Eiffel Tower to the Javanese Dancer: Envisioning Cultural Globalization at the 1889 Paris Exhibition," The History Teacher 41, no. 3: 339-62; and Stuart Hall, "Introduction," in Questions of Cultural Identity, ed. Stuart Hall and Paul du Gay (London: SAGE Publications, 1996), 1-17.

${ }^{57}$ Homi Bhabha, The Location of Culture (London: Routledge, 1994), 113-14.

58See: Mitchell, "Different Diasporas and the Hype of Hybridity," 533-53; and AlSayyad, "Hybrid Culture/Hybrid Urbanism," 1-16.
} 
experience chosen by individuals who want to use it to accomplish their goals, such as by being tolerant or mimicking the behavior of people from a different class in their everyday life.
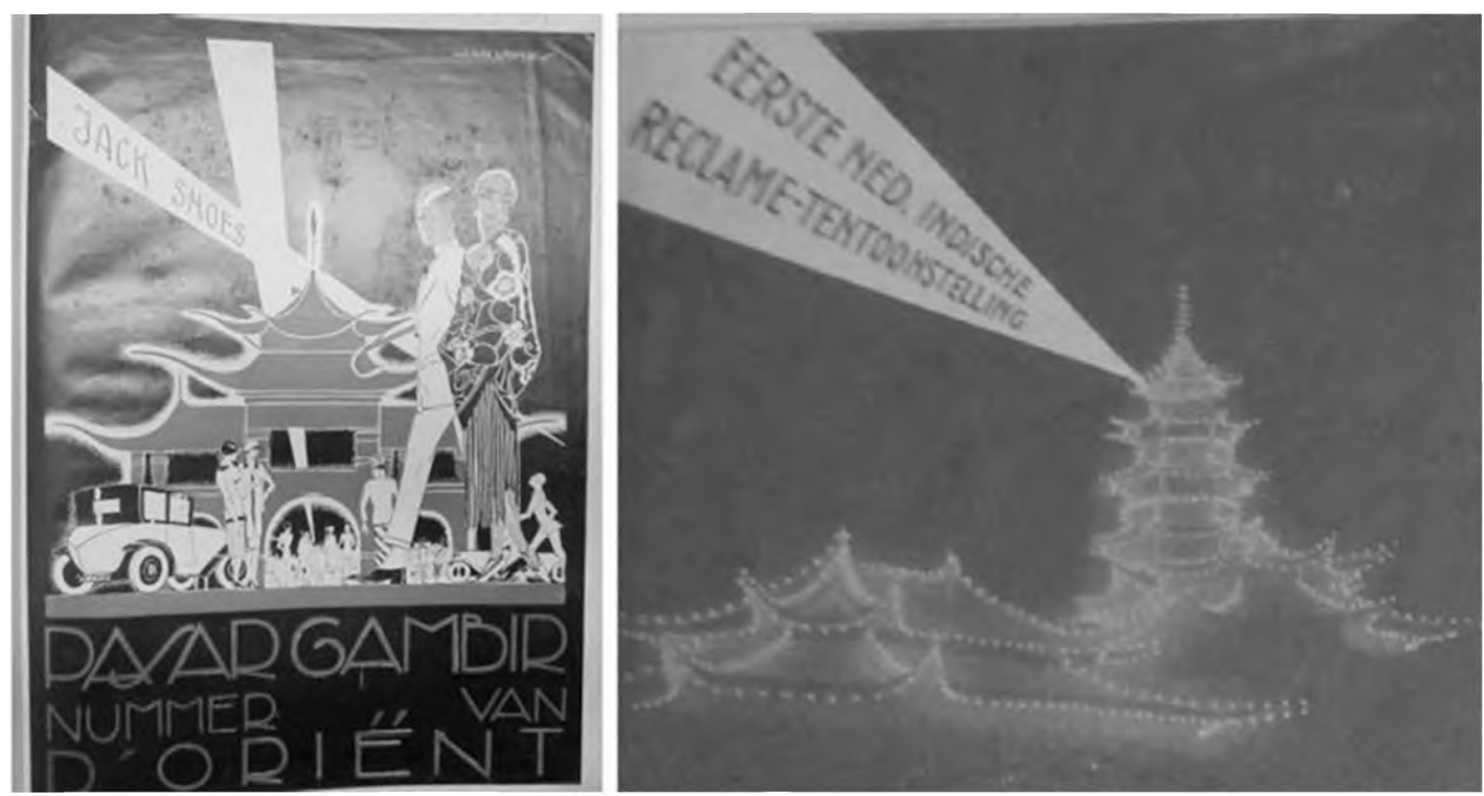

Figure 10: Electric lights at the 1925 Pasar Gambir. Source: D'Orient, September 1925

Pasar Gambir became an example of how individuals or social groups had agency to act within the rigid hierarchy and segregation of colonial society. The middle-class natives were allowed to enter the Western cultural sphere through appropriate behavior that imitated and reflected the colonizer's lifestyle and values. Pasar Gambir embodied the idea that this unique combination of a market and a fair could influence its visitors' behavior and change their mentality so as to be comparable to the Dutch. Both the Dutch and the natives struggled to maintain their position and identity according to certain social labels, which might be assigned by either or both parties.

Pasar Gambir's distinctive architectural forms contributed to reshaping local people's cultural identity, which allowed local visitors to create multiple associationsboth to local and Western values - to further their own social and cultural values. The architecture of Pasar Gambir summarized Indies culture, providing visitors with a panoptical vantage point over different Indies cultures then under Dutch rule. At the same time, it created a feeling of familiarity for local visitors because of the use of wellknown forms of Indies vernacular architecture. The effect was comfortable, since the architecture of the fair did not emphasize the originality of the forms and made the whole image of the building more important than the details. With the help of electric lights that gave an outline to the pavilions, the architecture of Pasar Gambir offered a modern experience to its visitors. The result of this experimental architecture might even induce pride among local visitors for having such inspiring local architecture.

Pasar Gambir offered insight into the relationship between the ruler and the ruled, by creating a place to "see and be seen," bringing together disparate cultures, and 
showcasing the pride that Pasar Gambir stimulated in its native visitors. To some extent, the discussion that Pasar Gambir generated was linked to Tony Bennett's idea of how the "exhibitionary complex" deliberated the power to order and arrange things for public display as objects and subjects of knowledge. ${ }^{59}$ Pasar Gambir echoed Bennett's idea that exhibitions are an alternative mode of authoritative communication, which eventually seeks to empower its visitors through education. Since everyone could see the exhibits and each other, the local middle class would be exposed to Dutch behavior ${ }^{60}$ The exhibition also promoted a self-regulating system in which visitors became conscious of their actions and, indeed, the greater forces of power. The poorest members of Indies society might have admired Pasar Gambir from a distance, since these people could not afford the admission tickets. But the Indies middle class was able to come to the fair and would be exposed to and learn how to emulate Dutch codes of behavior as well as imagine a new form of social relations.

A turn to traditional architecture to exhibit industrial progress and modern products provided a medium for the performance of cultural difference and delineated temporary social boundaries. The architecture of Pasar Gambir became a vehicle for celebrating social relations. The electric lights that outlined the pavilions were meant to accommodate this desire for and curiosity about modernity. For local visitors, the pavilions served as a starting point to take in modernity and to escape their ordinary life. The pavilions might be understood as symbols of unique social and cultural experiences to be shared by the Dutch and natives. It seemed that placing hybrid architecture under the eyes of visitors could bring to consciousness at once the whole Indies culture and the extension of Dutch power to modernize the colony.

Figure 11 shows visitors at the 1925 Pasar Gambir. The men wore white suitscommon clothing for Dutch men-and the women dressed either like Europeans or wore traditional kebaya. For Indonesians, speaking Dutch and mimicking the behavior of the Dutch meant appropriating Dutch culture and knowledge in order to seem to be equal to the Dutch. By doing this, the natives demonstrated a desire to achieve high status and be similar to the Dutch, even though this similarity could only exist temporarily, within the confines of the fair. For Dutch visitors, experiencing this kind of equality was also a unique experience. The temporary quality of the fair allowed the Dutch to feel comfortable about the situation, since they knew that the equality experienced there was also temporary, and only happened because of the fair. Although the Dutch government never meant for the Dutch and Indonesians to gain equal citizenship, Pasar Gambir became an arena where the categories of "Dutch as colonizer" and "native as colonized people" were temporarily vague.

\footnotetext{
${ }^{59}$ I borrow the phrase "exhibitionary complex" from Tony Bennett, who argues that nineteenth-century museums and, later, international exhibitions and arcades, were linked through shared practices of representation. The exhibition is described as an alternative mode of authoritative communication, which eventually seeks to empower its visitors through education. Tony Bennett, The Birth of the Museum: History, Theory, Politics (London: Routledge, 1995).

${ }^{60}$ Ibid., 63.
} 


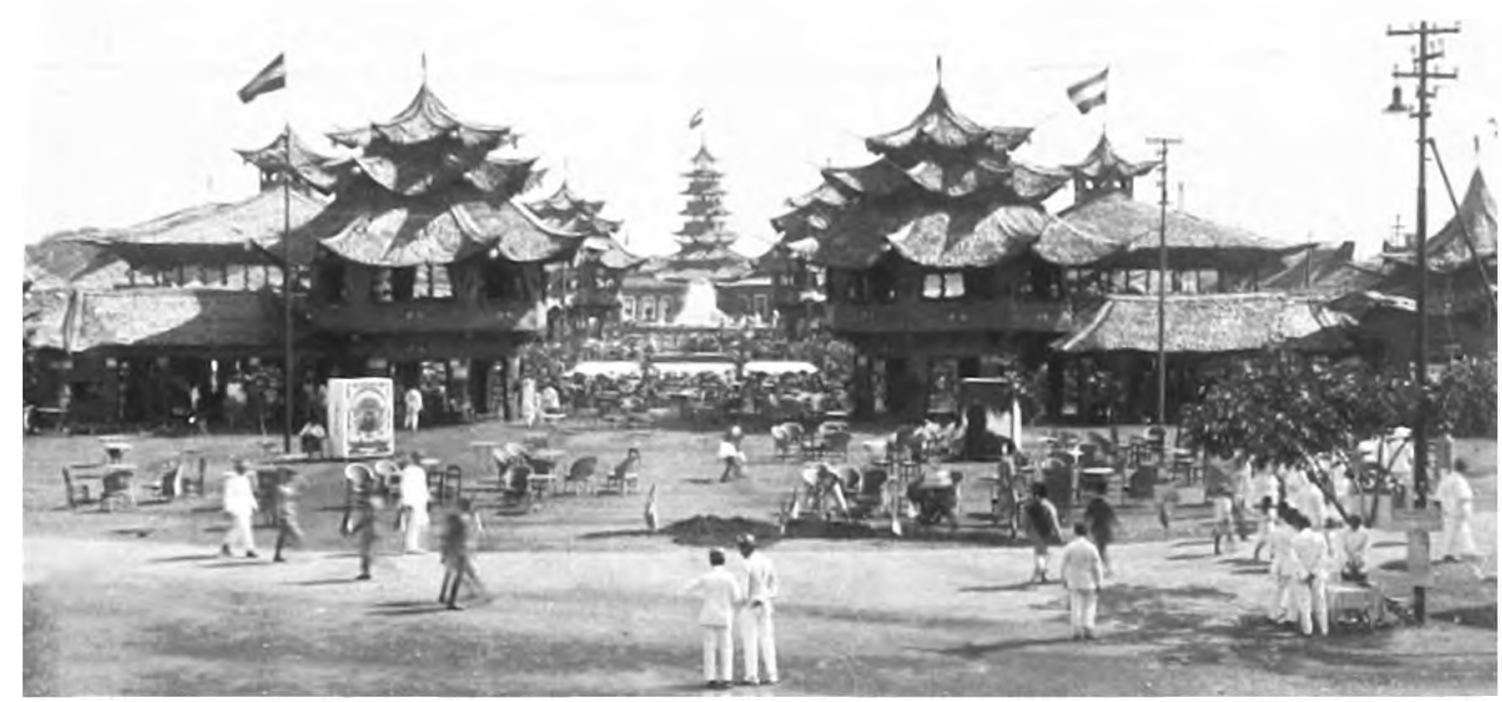

Figure 11: Visitors arriving at the 1925 Pasar Gambir Source: Nationaal Museum van Welerdculturen, Coll Nr.60041490

A letter written by an expatriate, Mrs. Kuyck, telling about her experience visiting Pasar Gambir in September 1929, illustrates the ongoing disparity between the colonizers and the colonized:

It is remarkable how differently the natives behave lately. They are not hostile, but many of them consider themselves completely equal to the Europeans. $[\ldots]$ When we left we saw a couple of native women and men at the entrance. They looked so neat and civilized $|\ldots|$ When we walked by I heard, again to my big surprise, that they spoke Dutch among themselves. ${ }^{61}$

In her letter, Mrs. Kuyck was surprised because the middle-class natives succeeded in mimicking their European counterparts' behavior. That the natives even spoke Dutch was seen as a sign of their desire and ability to lift themselves up to be like the Europeans. The description above also implied how practicing Western culture had been a crucial concept of the modern Indies.

Pasar Gambir's festive atmosphere was often used as the setting for novels, essays, and short stories. For example, in Sino-Malay monthly magazines, authors often used Pasar Gambir as a background or a popular meeting place for friends and lovers. In Dia Atawa Boekan?, for example, the author began the story with Pasar Gambir:

31 August! What a crowded day. There were many flags and big buildings. Inside Pasar Gambir, the situation was more crowded. People pushed and they could only move slowly between stands. Among Pasar Gambir's visitors that day, there were two young men dressed perlente [with style, elegant] ${ }^{62}$

\footnotetext{
${ }^{61}$ Quoted from Nordholt, "Modernity and Cultural Citizenship in the Netherlands Indies," 435-57.

${ }^{62}$ Tan King Tjan, "Dia Atawa Boekan," Boelan Poernama, June 1930. Boelan Poernama was a monthly Chinese Malay magazine targeted to Chinese living in the Indies, but the story was written in Bahasa
} 
August 31 is the Dutch queen's birthday, and people knew that there would be fireworks in Pasar Gambir to celebrate the queen's birthday. The author describes Pasar Gambir as very crowded that day. In the story, the two young visitors are described as perlente, in other words, chic and well-dressed. The two young perlente visitors fall in love at Pasar Gambir with twin girls - who wear European clothingand, on one occasion, these young visitors say "goodbye" in Dutch.

A local newspaper, Pandji Poestaka, reported on 1927's Pasar Gambir:

... how beautiful the buildings for Pasar Gambir. Undoubtedly [the fair] is crowded, even more crowded than last year. Security is tighter than before, and the lights of the fair are brighter. The spotlights are bigger than in any previous years and these lights shine farther. This is the place where we can see and learn about trading, companies, arts, and crafts; and also a place where we can have fun. In addition to the exhibits, there are also many entertainments in the fair. Nevertheless, know your limit: if you cannot afford it [the daily admission price], do not visit Pasar Gambir [more often than your finances will allow] ...63

That report suggests that, due to the earlier success of Pasar Gambir, improvements were added for the 1927 fair, such as security and lighting, and the exhibitions and shows were enhanced. The last sentence warned people not to attend the fair many times if they could not easily afford to buy the tickets. That indicates how easy it was for visitors to get caught up in Western-style consumerism.

As put forth by Anderson in Imagined Communities, colonialism made possible the idea of "nation" for the natives, where this idea never previously existed, by the introduction of maps, the census, and museums - including exhibitions. ${ }^{64}$ The spread of the idea of a nation was a product of modernity made possible by printed media, adjusted to local contexts to maximize the effect. ${ }^{65}$ In the case of Pasar Gambir, hybrid architecture, electric lights, print media, and displays of modern technology worked together not only to promote modernism but also to define the boundaries of the modern Indies. The fair's architecture suggested that the architecture and culture of the existing Indies needed material and intellectual enhancement to realize the promise of modern Dutch colonialism. Pasar Gambir's architecture, though not intentionally, might have provided a provocative, embryonic model for a potentially autonomous nation, for what became Indonesia.

Pasar Gambir became a meeting place and an escape from ordinary life. The hybrid architecture and class-free space of encounter at Pasar Gambir enabled creative interactions that sprang from colonization and intercultural contact, and resulted in new social and cultural expressions. At the very least, both European and Indonesian visitors wanted to see modern inventions and experience a social and cultural ambience that was different from their daily surroundings. Exposure to cultural modernity refers to the role of the individual in relation to equality, progress, and

Indonesia or Malay. In each edition, there was only one long story, around fifty pages, about the life of the Chinese people in the Indies.

${ }^{63}$ This is my translation of "Pasar Gambir," Pandj̈ Poestaka, August 19, 1927.

${ }^{64}$ Anderson, Imagined Communities, 163-85.

65 Ibid. 
mobility, and the condition where people experience a variety of new ideologies and lifestyles. Such exposure can be destabilizing, too, inasmuch as it encourages local people to be "self creative" and "imaginative" (which may work against the established social order) ${ }^{66}$ To a certain degree, local people did not submit completely to the notions of modernity and society constructed and emphasized by the Dutch, but instead embraced the idea of cultural citizenship - that is, they could claim and define modernity in their own ways. In his discussion on cultural citizenship, Schulte Nordholt argued that it was advertisements and school posters that illustrated the desires and the interests of the colonial regime, as well as invited members of the local urban middle class to become cultural citizens of the colony. In Pasar Gambir, I believe it was the architecture - together with its electric lights and advertisements - that were mainly used to invite a large number of local middle class people to become cultural citizens of the colony.

\section{A Laboratory of Modernity, Culture, and Society}

Instead of being ephemeral, Pasar Gambir-with its regular presence and promotion of modernity-began making festivities a permanent feature by offering popular entertainment and the temporary interruption of social convention. Pasar Gambir's hybrid architecture served to bring modernity to the Indies while also creating a hybrid space for locals and Western visitors. The use of Indies vernacular architecture gave natives a taste of modern lifestyles, although such exposure was temporary. In its celebration of crowds and modern culture, Pasar Gambir emphasized the colonial principle of order, but at the same time stimulated the agency of local people and conferred on them the power to imagine and conceptualize themselves as cultural citizens of a modern colonial state. Pasar Gambir's hybrid architecture became a kind of lingua franca that was meant to unite diverse elements of society and to connect the different conditions that exist between the ruler and the ruled.

In Pasar Gambir, the local middle class wanted to participate in modernity in the sense that locals wanted to become full, cultural citizens, rather than simply to become "modern" like their Dutch counterparts. Middle-class locals, who were presumably not so much interested in the nationalist movement, rather aimed to enjoy a modern lifestyle, experience modernity, and lessen the tense relationship with the Dutch. In the end, Pasar Gambir became a laboratory of modernity for the colony, and an important stage for modernizing and negotiating cultural and social conditions in the Indies.

${ }^{66}$ For a further discussion on modernity, see Arjun Appadurai, Modernity at Large: Cultural Dimensions of Globalization (Minneapolis: University of Minnesota Press, 1996). Also see Anthony Giddens, Modernity and Self-Identity (Stanford: Stanford University Press, 1991). 
